GLOBAL JOURNAL OF EDUCATIONAL RESEARCH VOL 14, 2015: 19-23

COPYRIGHT@ BACHUDO SCIENCE CO. LTD PRINTED IN NIGERIA. ISSN 1596-6224 www.globaljournalseries.com; Info@globaljournalseries.co

\title{
ENTREPRENEURIAL TRAINING AND PRE-RETIREMENT ANXIETY AMONG PUBLIC SERVANTS IN AKWA IBOM STATE, NIGERIA
}

\author{
J. S. PETTERS AND E. A. UWE
}

(Received 20, October 2014; Revision Accepted 21, November 2014)

\begin{abstract}
This study sought to determine if any relationship exists between entrepreneurial training of public servants and their pre-retirement anxiety. To achieve this, one hypothesis was formulated and tested at 0.05 level of significance. A sample size of 1,500 respondents was drawn from the population of all public servants in the state, through stratified random sampling and simple random sampling. A questionnaire was constructed, validated and administered to the respondents drawn from different departments and schools. The research design adopted for the study was Ex-post facto. Pearson Product Moment Correlation Coefficient was used for data analysis. The study revealed that there was a significant inverse relationship between entrepreneurial training and public servants pre-retirement anxiety. It was recommended that public servants should undergo entrepreneurial training for skill acquisition while still in service. There is need for appropriate enlightenment programmes on retirement issues to be periodically organized for workers by government and non-government organizations to effectively prepare them for retirement. This will help to alleviate pre-retirement anxiety and at the same time bring about sustainable livelihood in post-retirement years.
\end{abstract}

KEY WORDS: Entrepreneurial, training, retirement, anxiety

\section{INTRODUCTION}

Nigeria has witnessed various changes in her socio-economic landscape for over a decade now. One of the changes is related to the problems associated with ageing and retirement. Government's inability to cater adequately for the needs of the retirees is obvious. Most retirees are unable to sustain themselves and their families. They complain about the lack of commitment on the part of the government to pay on time their retirement entitlements. Nigerians have witnessed various demonstrations by retirees aimed at generating sympathy and awareness about their plights. Some retirees may slump in the process of waiting on long queue to receive their retirement benefits. The cost of health care in retirement is enormous since most people have the tendency to getting frequently ill as they grow older.
Retirement, an act of disengagement from active and gainful employment is an inevitable stage of human development for most workers. It is synonymous with loss of income and this is capable of affecting the quality and standard of life of a retiree. According to Aguluna\&Aguluna (2003), retirement leads to loss of steady income, reduction in status and social identity and reduced interpersonal relationships. Some retirees take up contract appointments, some work on part-time, some open private business ventures in order to augment their retirement benefits to sustain themselves and their families as a whole.

Generating or embarking on a new business venture with retirement benefits may be difficult especially if entrepreneurial skills are lacking. For this reason, the pre-retirees need to embark on entrepreneurial training in order to use their retirement benefits in a manner that will

J. S. PETTERS, Department of Educational Foundations, Guidance and Counselling University of Calabar,Calabar, Cross River State, Nigeria.

E. A. UWE, Department of Educational Foundations, Guidance and Counselling University of Calabar, Calabar,Cross River State,Nigeria. 
ensure increasing health and wealth for both the present and future generations. Aruwa (2006) views entrepreneurship as the willingness and ability of an individual to seek out investment opportunities to establish and run an enterprise successfully. Successful entrepreneurs often have the singular commitment towards serving others with their talents and creative abilities thereby aiding in development. Petters (2010) posits that entrepreneurship does not only lay emphasis on business venture or business opportunity recognition but concerns itself on initiative, imagination, creativity, a willingness to think conceptually and capacity to see change. It involves the transformation of innovative and creative ideas into profitable activities.

Entrepreneurial training for workers focuses on activities, trainings, conferences, workshops or general knowledge impacted on them to avail them of appropriate skills to prepare them adequately towards retirement (Mbon, 2006). It is a process of creating something new with value by devoting the necessary time and effort, assuming the accompanying financial, psychic and social risks and also receiving the resulting rewards of monetary and personal satisfactions and independence. To Ifelunni (2009) it is essential to train workers in creativity, risk taking, perseverance, innovativeness and problem solving orientation so that they can set up small business on their own on retirement. This will not only guarantee alternative sources of income but ensures that the retiree is in regular interactions with others.

Entrepreneurial education is necessary for the benefits of the Nigeria labour force and for national development. The concept of entrepreneurship in simple terms connotes getting involved in profitable business enterprise capable of leading to self-sufficiency (Onu, 2013). Retirement education is required as a means of equipping workers with reliable and relevant information to become self-reliance during postretirement years. Skills could be acquired in various aspects of life such as tailoring, hairdressing, cookery, bakery, hat-making, beads-making, photographing, farming (poultry, book binding, establishing daily, weekly, monthly, thrifts and loan service, dry cleaning service, computer service and so on. These of course are needed for sustainable development of any individual, family or nation.

According to James (2001), lack of preparation for retirement which may include lack of entrepreneurial training lead to the onset of anxiety when signal of retirement become imminent. Entrepreneurial training for workers will enable them to function effectively in selfemployment through small business entrepreneurship. This according to Ikenga, Ezoem, Udoye\&lsibor (2008) helps to abate preretirement anxiety and brings about development.

By pre-retirement anxiety one refers to a vague feeling of apprehension, worry, dread, panic, uncertainty, irritability exhibited by some public servants as they approach the mandatory retirement age. Anxiety is a pervasive and unpleasant feeling of tension, apprehension and feeling of an impending danger. It is a normal reaction of the body to anything capable of threatening one's body, values and lifestyle. A certain amount of anxiety exhibited by the body is normal and stimulat4es individuals to purposeful action. High levels of anxiety may lead to the development of certain forms of cardiovascular problems in some people. Most workers become anxious and confused as retirement approaches.

Some of the major causes of retirement anxiety according to Ode (2004) are inadequate fund, challenges in managing mental health, challenges in managing a new and lower social status, inadequate planning for retirement, difficulty in time management, total dependence on present salary, problem of securing residential accommodation, ignorance of what to do with pension money, attitude of friends, family and the challenges of sudden retirement. Symptoms of anxiety include irritability, confusion, tiredness, sweating, muscle tension, loss of control, restlessness, depression and nervousness. These symptoms may result in low productivity of workers which invariably may impair economic and sustainable developments. Hence, this work intends to find out if any relationship exist between entrepreneurial training of workers and their pre-retirement anxiety.

\section{Purpose of the study}

The purpose of this study is to find out the extent to which public servants' entrepreneurial training relate to the preretirement anxiety of public servants.

\section{Statement of hypothesis}

There is no significant relationship between entrepreneurial training and workers pre-retirement anxiety. 


\section{Methodology}

The research used ex-post facto design.

This is a design in which the researcher has no control of the independent variables because their manipulations had already occurred and therefore can no longer be manipulated. A sample of 1,500 subjects was randomly selected from Akwalbom State public service. It comprised of 741 males and 759 females. The offices were randomly selected from the overall number of offices in the area of study. Stratified random sampling technique was adopted to select the different groups in public service offices from where the simple random sampling technique was use to select the representative sample from each group. This implies that stratification was based on the various sections of the state public services which are the ministries, extra-ministerial departments, offices in the governor's office, primary schools and secondary schools.

\section{Instrumentation}

A questionnaire was used for data collection. It consisted of two sections $A$ and B. Section A elicited from the respondents their personal background data such as sex, age, educational qualifications and years of service. Section B was a ten item likert type scale that measured the respondents' involvement in entrepreneurial training. Positive items were directly scored while negative items were reversely scored.

\section{Data analysis and results}

The data collected was analyzed using the Pearson Product Moment Correlation Coefficient. The null hypothesis was tested at 0.05 level of significance.

\section{Hypothesis}

There is no significant relationship between entrepreneurial training and workers pre-retirement anxiety. Result is presented in table 1.

Table 1:

Pearson's correlation of the relationship between entrepreneurial training and public servants preretirement anxiety $(\mathrm{N}=1,500)$

\begin{tabular}{lcccc}
\hline Variables & $\begin{array}{c}\text { Rx } \\
\text { Ry }\end{array}$ & $\begin{array}{c}\mathbf{r x}^{\mathbf{2}} \\
\mathbf{r y}^{\mathbf{2}}\end{array}$ & $\mathbf{R x y}$ & $\mathbf{R}$ \\
\hline Public servants' & & & & \\
entrepreneurial training $(\mathrm{x})$ & 23656 & 378088 & & \\
Time Management $\left(\mathrm{y}_{1}\right)$ & 23602 & 377198 & 372226 & .001 \\
Meeting Basic Needs $\left(\mathrm{y}_{2}\right)$ & 24180 & 395812 & 380704 & $-.115^{\star}$ \\
Relocation $\left(\mathrm{y}_{3}\right)$ & 24818 & 419826 & 390386 & $-.149^{*}$ \\
Fallen standard of living $\left(\mathrm{y}_{4}\right)$ & 23536 & 373568 & 370876 & -065 \\
Loss of social contact $\left(\mathrm{y}_{5}\right)$ & 23624 & 379340 & 372694 & .021 \\
Total pre-retirement anxiety & 119760 & 9603264 & 1886886 & $-125^{*}$ \\
\hline
\end{tabular}

Significant at $.05 ; \quad d f=1,498 ; \quad$ critical $r=0.062$

Results of analysis in the above table shows that the calculated r-values for the relationship between entrepreneurial training and public servants pre-retirement anxiety over meeting basic needs (-.115), relocation (-.149), fallen standard of living (-.065) and for overall pre-retirement anxiety (-.125), though negative were each absolutely higher than the critical $r$ value of .062 at .05 level of significance with 1498 degrees of freedom. These results imply that there was a significant inverse relationship between entrepreneurial training and public servants pre-retirement anxiety over meeting basic needs, relocation and fallen standard of living and for overall pre-retirement anxiety. That is the more the entrepreneurial training received by a public servant, the less anxious such a public servant was over retirement with regards to the variables mentioned above. There was however no significant relationship between entrepreneurial training and pre-retirement anxiety over time management and loss of social contact.

\section{DISCUSSION}

Entrepreneurial training and preretirement anxiety relative to the hypothesis which speculated that the entrepreneurial training 
of public servants is not significantly related to pre-retirement anxiety, this null hypothesis was rejected. This study has revealed that entrepreneurial training is significantly related to pre-retirement anxiety. These results imply that there was a significant inverse relationship between entrepreneurial training and public servants pre-retirement anxiety over meeting basic needs, relocation and fallen standard of living and for overall pre-retirement anxiety.

This result of the study is in consonance with the work of Clark and Ambrosio (2003) who found that participation in entrepreneurial seminars changed individual's retirement goals and retirement saving behaviours in a positive way. This implies that such workers with entrepreneurial training exhibit less preretirement anxiety. The result of this finding lends credence to Bernheim and Garret (1996); Hershy and Mowen (2000); who equally found that brief training programmes (entrepreneurial) stimulated individual's saving behaviour and decision making competencies, this eventually reduces pre-retirement anxiety in public servants.

Furthermore, the result of this finding could be explained by the fact that entrepreneurial training for workers will help to acquire various entrepreneurial skills. This will enable them to function effectively in selfemployment through small business entrepreneurship, thereby abating pre-retirement anxiety. With acquired entrepreneurial skills, workers could establish and manage their own private businesses thereby aiding economic development. This finding is in line also with the study of Ifelunni (2009) who stated categorically that it is essential to train workers in creativity, risk-taking, perseverance, innovativeness and problem-solving orientation so that they can set up small businesses on their own on retirement. This will reduce pre-retirement anxiety as it will guarantee alternative sources of income for immediate family.

However, Agulanna and Agulanna (2003) explained that, currently in Nigeria, the hardship being faced by the retirees for not possessing entrepreneurial skills has taught those currently working, a big lesson. Most workers would wish to go for entrepreneurial training before retirement in order to enhance themselves economically in preparation for post-retirement years.

Workers should realize the fact that they live in a progressive world, where the desire to be innovative and creative is the needed approach for economic as well as family development.
Even when at retirement, the retirees become weak with decreasing strength, they can still play the role of being directors by supervising their various businesses. Their world of experience will go a great length in family and national development. By so doing, they will keep active and live longer. Retirement does not however imply freedom from work but freedom to work. The crux of this finding is that entrepreneurial training of workers act as tonic towards reducing pre-retirement anxiety and economic recessions.

This implies that the more the worker is exposed to the process of entrepreneurial training, the less the level of pre-retirement anxiety exhibited by such worker. Thus entrepreneurial training is significantly related to pre-retirement anxiety of workers. Such training aids in the sustainability of the individual, family and nation at large.

\section{CONCLUSION/RECOMMENDATIONS}

This work examined the relationship between entrepreneurial training and worker's pre-retirement anxiety. The study was carried out among public servants in Akwalbom State, Nigeria. Findings indicate that workers who get involved in entrepreneurial training to acquire skills for self-employment become less anxious as mandatory retirement approaches. Given the above result, it becomes pertinent to recommend that public servants should be encouraged to embark on entrepreneurial training in order to acquire lifelong skills which can be utilized to earn extra income for sustainable family development. This may help to reduce boredom at post-retirement years. Government and nongovernmental organizations should as a matter of deliberate policy realize the need to periodically organize training programmes, seminars and workers for their employees on how to acquire entrepreneurial skills for sustainable development.

\section{REFERENCES}

Aguluna, E. C and Aguluna, G. C., 2003. Management of retirement and ageing. Owerri: Joe Mankpa Publishers.

Bernheim, B. D and Garret, D. M., 1996. The effects of financial education in the workplace: Evidence from a survey of households. Journal of Public Economics, 87, $1487-1519$. 
Clark, R. Land d'Ambrosio, M. C., 2003. Ignorance is not bliss: The importance of financial education. TIAA - CREF Research Dialogue, 74, 1 - 14.

Heershey, D.A andMowen, J. C., 2000. Psychological determinants of financial preparedness for retirement. The Georontologists, 40, $687-697$.

Ifelunni, I. C. S., 2009. Ageing and retirement planning in Nigeria - A lead paper presented at the $4^{\text {th }}$ Memorial lecture of Pope John Paul II Major Seminar, Auka, $31^{\text {st }}$ March $-2^{\text {nd }}$ April.

Igbokwe, U. I., 2008. Education for sustainable retirement: Implications for curriculum planning. Journal for Educational Foundations, 5(2), $203-209$.

Ikenga, G. U.Ezoem, M. N.,Udoye, R. N andlsibor, A. O., 2008.entrepreneurial the panacea for post-retirement predicaments. A paper presented at $1^{\text {st }}$ International Conference, Dept of Educational Foundations, University of Nigeria, Nsukka, $29^{\text {th }}$ July $-2^{\text {nd }}$ August.

James, V. O., 2001. New thoughts old age. New York: Springer Press.

Mbon, U. F., 2006.Primary school teachers' perception of organizational retirement plans and their attitudes to work in Southern Senatorial Cross River State. Journal of Educational Foundations. $5(1), 73-79$.

Ode, T. A., 2004.Counselling for retirement adjustment. A paper presented at the $28^{\text {th }}$ Annual National Conference of the Counselling Association of Nigeria (CASSON). Maiduguri.

Onu, C. C., 2013. My career guide, schools and colleges. Enugu: Mercilink Computers and Publishers

Petters, J. S., 2010.Personal-social characteristics and pre-retirement anxiety among public servants in Akwalbom State, unpublished Ph.D Thesis, University of Calabar, Calabar. 